\title{
LEGAL PROBLEMS INVOLVED IN THE PRESCRIPTION OF CONTRACEPTIVES TO UNMARRIED MINORS IN ALBERTA*
}

\author{
RICHARD J. GILBORN**
}

\begin{abstract}
Mr. Gilborn's article deals with the thorny problem of the prescription of contraceptives to unmarried minors. In order to appreciate the legal difficulties involved in the area, an examination of the ability of minors to consent to medical treatment in general is undertaken. Using the 'mature minor' rule, as a base, it has to be considered whether the treatment involved is such as to fall within its scope. The article then examines the various ways in which a doctor might be made liable. The author considers possible civil liability, criminal and quasi-criminal liability under the Criminal Code and the Food and Drug Act, and finally the issue of whether the prescription of contracep. tives could be viewed as contributing to juvenile deliquency under the Juvenile Delinquents Act. Lastly, the article considers the possibility of disciplinary proceedings launched by professional bodies as a possible risk in the prescription of contraceptives. The article concludes with a series of recommendations as to how the law in this area may be rendered more clear not only in the field of the prescription of contraceptives but in the area of a minor's ability to consent to medical treatment in general.
\end{abstract}

\section{INTRODUCTION}

The problem to be examined in this paper is the legality of prescribing contraceptives to unmarried minors in Alberta. ${ }^{1}$ This problem inevitably involves complex and controversial issues in the religious, social and legal fields. This paper will make no attempt to argue for or against the religious or social desirability of the prescription of contraceptives to unmarried minors, but will, as far as possible, concentrate on the legal issues involved.

Some of the complex legal questions involved include: (i) Are there any criminal or civil sanctions involved in the prescription of contraceptives to unmarried minors without parental consent? (ii) At what age if any, can a minor give valid consent to medical treatment? (iii) Is the prescription of a contraceptive a "medical treatment"? Even though there may be no absolute answers, it is hoped the material presented will shed some light on these difficult legal questions.

At the same time it is fully recognized that it would be foolish, if not impossible, to ignore all the thorny moral and social problems involved. During the course of research it was very obvious that much of what has been written on this subject is colored by a writer's particular personal beliefs. Members of the medical profession hold very strong and often differing views about the ethical question of whether they should prescribe contraceptives for unmarried minors. Some feel that the prescription of contraceptives or the provision of birth control information to unmarried minors encourages immorality and venereal disease among the young. Others feel that the welfare of their patients is best served by preventing illegitimacy and unwanted immature pregnancy. A typical example of these radically opposed viewpoints can be found in an article entitled Contraceptives for Teenagers?:2

- This paper was written for the Institute of Law Research and Reform and appears with their permission.

* B.A., L.L.B. of the graduating class.

1 The Age of Majority Act, S.A. 1971, c. 1, lowered the age of majority in Alberta from 21 to 18.

2 Ayd, Medical Science, September 1967, 20 at 24. 
Those of us whose responsibilities include the care of young unmarried mothers must certainly feel compassion for the distressing problems that the unwed mother, her family and the unwanted child must face ... it should be realized that a health hazard exists and that a safe method for protection against pregnancy is the proper and only humane treatment....

... I am opposed to offering birth control information to unmarried adolescent girls (under 18 years) in must circumstances. Since the purpose of seeking such information is to make intercourse possible without danger of pregnancy and since I am opposed to casual intercourse by adolescent girls I can see no logical reason for giving contraceptive advice to girls in this age group.

These two opinions, though very different, are both given by eminent physicians primarily concerned with their patients' welfare. Viewed in this context we see that the legal problem is only one part of a larger controversy.

\section{MINORS' CONSENT TO MEDICAL TREATMENT}

This section of the paper will be concerned only with the problem of determining at what age (if any) a minor can give valid consent to medical treatment. The consequences arising from the lack of valid consent will be examined in Part III, infra.

At the present time in Alberta there is no statute dealing with age of consent for medical treatment. It would seem that this is the situation in the majority of Canada's provinces. ${ }^{3}$ The position, therefore, is entirely dependent on the common law. Lord Nathan suggested in his classic work on medical negligence that: ${ }^{4}$

... [A]n infant who is capable of appreciating fully the nature and consequences of a particular operation or of particular treatment can give an effective consent thereto, and in such cases the consent of the guardian is unnecessary;... It may, however, be necessary to add to the proposition suggested above the rider that a surgeon or physician will, in any event, only be able to rely upon the infant's consent as a defence where he performed the operation or administered the treatment bona fide in the interests of the infant's own health.

A few years later W. F. Bowker suggested three rules with respect to the consent of a minor to medical treatment: ${ }^{5}$

The requirement of consent to therapy for the minor can be described as follows:

1. Where he is mature and has left home, he can give his own consent, just as an aduit can;

2. Where he is mature and living at home, the position is the same as in 1 ;

3. Where he is "of tender years" the guardian's consent is necessary.

Two recent articles in Canada also agree with the general proposition that a "mature minor" can give valid consent to medical treatment. 6 Both of these articles cite as authority for this proposition Johnston v. Wellesley Hospital, a recent decision of Addy J. in the Ontario High Court. ${ }^{7}$ In Ontario, at the time of this decision, the age of majority was still 21; nevertheless, it was held that a twenty year old could validly consent to a cosmetic treatment for facial scars even

\footnotetext{
' Bowker, Experimentation on Humans and Gifts of Tissue: New Articles 20.23 of the Quebec Civil Code, draft of article to be published in Vul. 19-2, McGill L.J.. at 18 of draft. B.C. recently passed an amendments to their Infants ${ }^{\circ}$ Act which set the age of consent to medical treatment at 16. Bill 37 was assented to on April 18, 1973. Saskatchewan's Legislature recently defeated such legislation. See infra, n. 64.

- Lord Nathan, Medical Neglipence' 176-177 (1957).

: Bowker, Legal Liability to Volunteers in Testing New Drugs (1963) 88 Can. Med. Assoc. J. 745 at 749.

- Bowker, supra, n. 3; See also, Wadlington, Minors and Health Care: The Age of Consent (1973) 11 Osgoode Hall L.J. 115.

; (1970) 17 1).L.K. (3d) 139 .
} 
though there was definitely no question of an emergency involved. The court expressly approved Lord Nathan's view of the law. ${ }^{8}$

One other Canadian case which has held that a mature minor can validly consent to a medical operation is Booth v. Toronto General Hospital. ${ }^{9}$ In that case a youth of nineteen years of age who was earning his own living, was held to be capable of consenting to a throat operation beneficial to his health.

Some of the reasoning behind the establishment of this "mature minor" rule is given as: ${ }^{10}$

Whatever may be the position in the United States, a mature minor under Canadian law may consent to the risk of injury. He may do so even where the risk is that of damage from another's negligence. This being so, he can obviously agree to medical or surgical treatment which is for his benefit.

Very similar to this reasoning is that given in the Johnston case: ${ }^{11}$

If a person under 21 years were unable to consent to medical treatment, he would also be incapable of consenting to other types of bodily interference. A proposition purporting to establish that any bodily interference acquiesced in by a youth of 20 years would nevertheless constitute an assualt would be absurd. If such were the case, sexual intercourse with a girl under 21 years would constitute rape. Until the minimum age of consent to sexual acts was fixed at 14 years by a statute, the Courts often held that infants were capable of consenting at a considerably earlier age than 14 years.

Of course, since the time of the Johnston case, the age of majority in Alberta has been lowered to 18. The first and obvious effect of this statutory enactment is to make it clear that sui juris persons of 18 years of age or more can give valid consent to medical treatment. At the time that the Age of Majority Act was passed in Alberta no specific provision was made with respect to consent to medical treatment. ${ }^{12}$ This differs with the English position under the Family Law Reform Act, 1969. This Act, based on the recommendations of "The Latey Report", lowered the age of majority to 18 and included a specific section allowing a minor of 16 years of age or more to give a valid consent to medical treatment: ${ }^{13}$

8. (1) The consent of a minor who has attained the age of sixteen years to any surgical, medical or dental treatment which, in the absence of consent, would constitute a trespass to his person, shall be as effective as it would be if he were of full age; and where a minor has by virtue of this section given an effective con. sent to any treatment it shall not be necessary to obtain any consent for it from his parent or guardian.

(2) In this section "surgical, medical or dental treatment" includes any procedure undertaken for the purposes of diagnosis, and this section applies to any procedure (including, in particular, the administration of an anaesthetic) which is ancillary to any treatment as it applies to that treatment.

(3) Nothing in this section shall be construed as making ineffective any consent which would have been effective if this section had not been enacted.

It may be significant to notice that subsection (3), in accordance with the Commission's recommendation, is a saving section. This

"Id. at 145.

(1910) 17 O.W.R. 118 per Falconbridge C.J.K.B.

to Bowker. supra, n. 5.

"Johnston v. Wellesley Hospital, supra, n. 7 at 144-145.

12 The problem was briefly mentioned in appendix B of the Age of Majority-Report No. 4 of the Alberta In. stitute of Law Research and Reform, but no recommendation was made.

is The Fiamily L,aw Keform Act, 1969, c. 46, s. 8. 
would seem to imply that the common law rule of a "mature minor's" consent to medical treatment may still apply so that even a minor below the age of 16 may validly consent to medical treatment. On the other hand it may only be saving the common law rule that no consent is necessary where it cannot immediately be obtained and there is an emergency situation.

On the basis of what case law there is and on the basis of the legal opinions cited, supra, it would seem fairly safe to state that the common law recognizes that a "mature minor" can effectively consent to a medical treatment the nature of which has been explained to him, which he can sufficiently understand, and which is for his benefit. Perhaps the most pressing question for the purposes of this paper, however, is at what age, if any, one can generally assume a minor is mature enough to consent to and understand a particular medical treatment. Would that age be 16 or over, or would it be 14 or over-or younger?

Among the reasons given by The Latey Report for recommending that the age of 16 be used was that it was also the age of consent to sexual intercourse in Britain. ${ }^{14}$ This may provide some clue as to what age we can consider to be the age of consent for medical treatment in Canada.

The relevant sections of the Criminal Code $^{15}$ concerning the age of consent to sexual intercourse are:

146. (1) Every male person who has sexual intercourse with a female person who (a) is not his wife, and

(b) is under the age of fourteen years,

whether or not he believes that she is fourteen years of age or more, is guilty of an indictable offence and is liable to imprisonment for life.

(2) Every male person who has sexual intercourse with a female person who

(a) is not his wife,

(b) is of previously chaste character, and

(c) is fourteen years of age or more and is under the age of sixteen years, whether or not he believes that she is sixteen years of age or more, is guilty of an indictable offence and is liable to imprisonment for five years.

(3) Where an accused is charged with an offence under subsection (2), the court may find the accused not guilty if it is of opinion that the evidence does not show that, as between the accused and the female person, the accused is more to blame than the female person.

151. Every male person who, being eighteen years of age or more, seduces a female person of previously chaste character who is sixteen years or more but less than eighteen years of age is guilty of an indictable offence and is liable to imprisonment for two years.

Section 146(1) makes it clear that an unmarried minor female under the age of 14 can under no circumstance consent to sexual intercourse. If it is valid to compare the age of consent to medical treatment to that of intercourse, it would seem reasonable to hypothesize that Parliament would not consider a child under the age of 14 capable of giving a valid reasoned consent to contraceptive medical treatment. Whether a court of law would view the question in the same way is wholly a matter of conjecture. It would seem reasonable, however, to suggest that a medical practitioner would generally be ill advised to accept solely the consent of a thirteen year old girl for contraceptive medical treatment, when Parliament has provided that such a child is incapable of

\footnotetext{
1" Report of the Committee on The Age of Majority, Para. 481 (1967).

1. R.S.C. 1971), c. C-34, as amended S.C. 1972, c. 13.
} 
consenting to sexual intercourse. It is well settled, of course, that the consent of a minor or an adult is implied in an emergency situation where the person authorized to give consent is unavailable or incapable of giving such consent. ${ }^{16}$ It would be greatly stretching the point to suggest that the prescription of contraceptives involves an "emergency" situation.

At this point it may be useful to note that provisions in the Criminal Code with respect to the age of consent to sexual intercourse by young males are conspicuous by their absence. Whether the reason for this is physiological or historic is not known. In any case this paper will assume that if a consensus can be reached as to the proper age of consent to medical treatment for females the same will apply to males.

Though it may seem fairly reasonable to arrive at the conclusion that in general minors under the age of fourteen could not give a valid consent to medical treatment with respect to birth control, the situation with respect to minors in the two age groups 14-15, and 16-17 would seem much less clear. In these two age groups sections $146(2),(3)$ and 151 would seem to imply that such female minors could not generally consent to sexual intercourse if they were previously of chaste character and were not more to blame than their male partner. There is great difficulty in trying to apply these complex considerations to the problem of the age of consent to medical treatment. Prima facie, it would appear that a medical practitioner could probably rely on the sole consent of a sexually active minor in these two age groups since it would seem such a sexually active minor would not be of "previously chaste character" within the meaning of that term in sections 146 (2) and 151. "Previously chaste character" has been defined as follows:17

Previous chaste character means moral cleanliness in the sense that a reasonable number of right-thinking persons who are aware of her conduct would say there is an absence of sexual impropriety and indecency.

It has also been held that these words do not refer to a physical condition alone. ${ }^{18}$

There has been one case in Canada however, that suggests a medical practitioner may face disciplinary proceedings if he does not obtain parental consent before prescribing contraceptives to unmarried girls under 16 years of age. ${ }^{19}$ The $R e$ " $D$ " case was an appeal from a decision of the Council of the College of Physicians and Surgeons of British Columbia upholding the decision of a medical inquiry committee which found that three of eight charges made against Dr. " $D$ " following the complaints of a 15-year-old female patient, were proven. The charges appealed from were:

2. That you have been guilty of infamous or unprofessional conduct in inserting a birth control device in a 15-year-old female patient... on or about March 28th, 1968 without parental consent.

3. That you have been guilty of infamous or unprofessional conduct in intentionally not disclosing the treatment or purported treatment referred to in Charge 2 and further treatment or purported treatment to the same patient on April 13th, 1968 to the parents of the said patient at the time of such treatment.

16 See e.g., Wadlington, supra, n. 6 at 116.

$17 R$. v. Shaw $[1964] 1$ C.C.C. 104 (N.S.S.C.).

in $R$. v. Lougheed (1903) 8 C.C.C. 184 (N.W.T.S.C.).

19 Re "D" (1970) 11 D.L.R.(3d) 570 (B.C.S.C.). 
4. That you have been guilty of infamous or unprofessional conduct in conducting yourself indecently with a female patient... on or about March 28th and April 13th, 1968 by kissing her and fondling her private parts.

The appeal against these charges was dismissed, MacFarlane J. having found on the main question of appeal that the medical inquiry committee made a deliberate effort to find corroborative evidence. For the purposes of this paper, however, the appellant's second main ground of appeal was the most important. It was argued that "there is nothing improper about a doctor taking a 15-year-old girl as a patient and giving her medical treatment without the consent of her parents." It was further contended "... that once the doctor accepts the patient then he is bound by his code of ethics ... to keep secret from everyone, including the parents of the child, what transpires between him, as a doctor, and the child, as a patient."20

To this argument the court seems to answer that in some circumstances this may be true, but whether or not a given conduct is unprofessional or infamous in a particular set of circumstances is something best decided by a medical inquiry committee and they had decided that in this case the conduct was unprofessional. ${ }^{21}$

From the standpoint of attempting to derive a ratio decidendi this finding by the court is very unsatisfactory. It does not tell us what conduct is unprofessional-i.e., is the insertion of an I.U.D. in a 15-year-old girl without parental consent unprofessional conduct per se or does it become unprofessional conduct only on the facts of this case-where there was an allegation of sexual impropriety (which was accepted) and where the parents were informed by the daughter of the insertion of the I.U.D. and asked that Dr. "D" remove it? This question can only be fully answered by subsequent cases. It is submitted, however, that this case should not be cited as authority for the proposition that 15-year-old girls can never validly consent to contraceptive treatment without parental consent. The problem in the case was approached largely as one of fact, there was no question of battery involved, and the court did not even discuss the legal capability of a 15-year-old to consent to medical treatment. Perhaps the most one could say this case decides about the problem of a minor's consent to contraceptive treatment, is that it is a question of fact in all the circumstances of the case and that it offers little in the way of guidelines for a court or medical inquiry committee to follow in determining such a question.

Finally one must consider the 16-17-year-old age group and their consent to medical treatment in general, and contraceptive treatment in particular. As mentioned before it is an indictable offence under the Criminal Code for a male over 18 to seduce a female of this age group, who was previously of "chaste character". Does this indicate that such a minor is incapable of consenting to contraceptive treatment unless she is already sexually active or that a medical practitioner would have to determine if his patient was not of "chaste character" before he prescribed contraceptives?

In the writer's opinion a medical practitioner could legally rely on the consent of a minor in this age group if he was reasonably satisfied that the nature of the treatment was properly explained to the minor,

\footnotetext{
211 Id. at 577.

$\therefore$ Id. at 577.578 .
} 
properly understood, and in the general health interests of the child. It is further suggested that if in a medical practitioner's opinion, the general health and development of such a minor would best be served by the prescription of contraceptives, he would be safe in prescribing the same without the parent's consent if in his discretion he felt it was not necessary or possible to obtain.

This opinion is based in part on the Johnston and Booth cases. ${ }^{22}$ Though admittedly these cases concerned minors of the age of 20 and 19 at a time when the age of majority was 21 , it is suggested that there is no reason in principle why the "mature minor" rule that these cases help to establish cannot encompass minors of age 16 or 17 . There would seem to be no reason in fact or principle why such minors could not generally be felt to be fully capable of giving a fully reasoned and informed consent to medical treatment.

The provincial legislatures across Canada have arrived at the conclusion that people having reached the age of 18 years, instead of 21 , are fully responsible as adults for the decisions they make and the actions they undertake. It therefore seems to follow that if a "mature minor" rule does indeed exist, the mature minors we are now concerned with are in the 16-18-year-old age group whereas they were at one time in the 18-20-year-old age group (if not indeed much lower than that).

It is suggested that the common law is keeping pace with modern times and modern statutes in recognizing the dwindling control of parents over the actions of mature minors. As authority for this view a recent statement made by Lord Denning, M.R. in the Hewer v. Bryant case can be cited: 23

I utterly reject the notion that an infant is, by law, in the custody of his father until he is 21. These words "in the custody of a parent" were first used in the Limitation Act 1939. During the next year youngsters of 18 and 19 fought the Battle of Britain. Was each of them at that time still in the custody of his father? The next use of the words was in the Law Reform (Limitation of Actions, etc.) Act 1954. Since which time pop singers of 19 have made thousands a week, and revolutionaries of 18 have broken up universities. Is each of them in the custody of his father? Of course not. Neither in law nor in fact. Counsel for the defendant realized the absurdity and sought to graft exceptions on to the rule in Re Agar-Ellis. But he failed to provide any satisfactory definition of his exceptions. By the time he finished, it looked to me as if the exceptions would swallow up the rule. I would get rid of the rule in Re Agar-Ellis and of the suggested exceptions to it. That case was decided in the year 1883. It reflects the attitude of a Victorian parent towards his children. He expected unquestioning obedience to his commands. If a son disobeyed, his father would cut him off with one shilling. If a daughter had an illegitimate child, he would turn her out of the house. His power only ceased when the child became 21 . I decline to accept a view so much out of date. The common law can, and should, keep pace with the times. It should declare, in conformity with the recent report on the Age of Majority, that the legal right of a parent to the custody of a child ends at the eighteenth birthday; and even up till then, it is a dwindling right which the courts will hesitate to enforce against the wishes of the child, the older he is. It starts with a right of control and ends with little more than advice.

Before leaving this area it is necessary to mention two possible caveats to the opinion that 16 and 17-year-olds would generally be capable of consenting to medical treatment including contraceptive treatment. These are the suggestions that the prescription of contraceptives to minors is not a "medical treatment" since it has no therapeutic value, 
and the definition of a child within the Juvenile Delinquents Act, which in Alberta differs for males and females.

It would seem that nearly all statements of the "mature minor" rule include as part of the test for the application of this rule that the particular medicil treatment must be for the minor's benefit. ${ }^{24}$ This question of "benefit" has generally been examined in the context of experimentation on tissue or organ donation. For example, a United States District Court of Appeals has held that a minor of 15 could not consent to a skin-graft operation which was not for his benefit-but for the benefit of his badly burned cousin. ${ }^{25}$ This reasoning would hardly seem to apply to the prescription of contraceptives. If there is any benefit to be derived it would certainly fall on the minor for whom the contraceptives were prescribed.

It may be argued in this context, however, that there can really be no benefit to a minor from a particular "medical treatment" unless there is some therapeutic value derived from the treatment. Nevertheless, at least some suggestion has. been made that there is therapeutic value in the prescription of contraceptives to minors. The following passage is an example: ${ }^{26}$

The National Medical Advisory Committee of Planned Parenthood, along with many other prominent authorities in the field of medicine, have recognized that the sexually active minor faces many serious health hazards to herself and her children if she is not provided access to medically approved fertility control methods. ${ }^{2}$ These hazards, demonstrated by numerous studies, include greatly increased risk of prematurity, stillbirth, perinatal and infant mortality and brain injury to the child born. ${ }^{3}$ Should the child survive birth, he stands a much higher than average risk of dying or being damaged through ignorance or neglect of the mother, or of being actually battered, burned or starved. 4 Similarly, in terms of material mortality and morbidity, the teenage mother is "high risk" medically in almost every respect, during pregnancy and at childbirth. ${ }^{5}$

Whether or not the prescription of contraceptives is generally a therapeutic treatment is largely a medical question which cannot be hoped to be fully answered in this paper. Similarly, the very difficult moral and religious question of whether the prevention of conception is a "benefit", is beyond the scope of this paper.

Before leaving this area, one must consider what effect, if any, the definition of a "child" within the Juvenile Delinquents Act may have

$\because$ See e.g., Bowker, supra, n. 5 at 749; Wadlington, supra, n. 6 at 119; Nathan, supra, n. 4 at 177. See also, Pilpel, Minors' Rights to Medical Care, 36 Albany L.R. 462 at 466 , for U.S. position.

as Bonner v. Moran (1941) 126 F. 2d 121; this case was quoted in both Bowker, supra, n. 3 at 22 and Wadlington, supra, n. 6 at 118

26 Pilpel and Wechsler, Birth Control, Teenagers and the Law, (1961) 1 Fam. Planning Perspectives 29. The authority cited by the authors for the statements made in this passage are:

1. Planned Parenthood National Medical Advisory Committee Statement, Oct. 10, 1069; Committee on Public Health; Bull. New York Acad. Med. 41: 410, (1965); and J. Am. Med. Assoc. 190: (1964).

2. Butler and Bonham, Perinatal Monthly, Edinburgh and London (1963); Heady and Morris, 1969) 66, J. Obst. \& Gynaec. Brit. Emp. at 577; Yerushalmy, Bierman, Kemp, Connor, and French, (1956) 71, Am. J. Obst. \& Gynec. at 80; Illsley, "The Social Correlates of Childbirth," paper for Perinatal Research Committee, Association for the Aid of Crippled Children (1964); and U.S. Dept. of Health Education and Welfare: International Comparison of Perinatal and Infant Mortality: The United States and Six West European Countries, (1967); Kessler, "Maternal and Infant Mortality", Proceedings of the International Planned Parenthood Federation (1967).

3. Simons, et al., "Child Abuse-Epidemiologic Study of Reported Cases", (1966) N.Y. State Journal of Medicine, at 2783-2787.

4. Yerushalmy, Palmer, and Kramer, (1940) 55 Pub. Health Reports at 1195; Jaffe and Polgar, "Medical Indications for Fertility Control", unpublished paper, Planned Parenthood-World Population; Parker, Rosner, Jacobziner, and Greenstein. (1961) 51 Am. J. Pub. Health at 846; and Kessler, "Maternal and Infant Mortality", Proceedings.of the Intemational Planned Parenthood Federation (1967). 
on the age at which a minor may consent to medical treatment. Section 2(2) of the Juvenile Delinquents Act, ${ }^{27}$ provides:

(2) The Governor in Council may from time to time by proclamation

(a) direct that in any province the expression "child" in this Act means any boy or girl apparently or actually under the age of eighteen years, and any such proclamation may apply either to boys only or to girls only or to boys and girls, and

(b) revoke any direction made with respect to any province by a proclamation under this section, and thereupon the expression "child" in this Act in that province means any boy or girl apparently or actually under the age of sixteen years.

At present the rather ambiguous position in Alberta is that a "child" within the Juvenile Delinquents Act is defined as any boy apparently or actually under the age of 16 years and any girl apparently or actually under the age of 18 years. ${ }^{28}$ In order to determine if this definition of "child" should have any effect or influence on the minimum age of valid medical consent, the purpose of the Juvenile Delinquents Act should be examined.

The broad purpose of the Act would seem to be the rehabilitation of juvenile offenders and the protection of children from the rigors of our normal criminal procedure. ${ }^{29}$ In the writer's opinion the legislative enactment of upper age limits for this protection ${ }^{30}$ is not nearly the same thing as saying mature minors under these age limits are not capable of understanding a medical treatment and validly consenting thereto. It could be argued, however, that the prescription of contraceptives to a "mature minor" girl under the age of 18 may leave a doctor open to a charge of contributing to juvenile delinquency. The validity of this argument will be examined in Part $C$.

\section{POSSIBLE LIABILITY OF A PHYSICIAN FOR THE TREATMENT OF MINORS WITHOUT PROPER CONSENT}

(a) General Position

\section{Civil Liabilities}

Salmond on the Law of Torts states:31

The application of force to the person of another without lawful justification amounts to the wrong of battery. This is so, however trivial the amount or nature of the force may be, and even though it neither does nor is intended nor is likely or able to do any manner of harm. Even to touch a person without his consent or some other lawful reason is actionable.

No action can be maintained, however, by a person who has expressly or impliedly consented to an act which would otherwise amount to a battery. In this way then, the maxim-volenti non fit injuria-generally "... affords a defence to a physician or surgeon for an act done in the proper course of medical or surgical treatment."32

In order for a patient's consent to be effective it must be a fully in-

\footnotetext{
$n$ R.S.C. 1970, c. J.3.

2N See S.O.R./51-461, Part II Canada Gazette (1951) at 1069.

75ee e.8., 8. 3(2), Juvenile Delinquents Act, R.S.C. 1970, c. J-3.

so Note s. 9 which allows a juvenile court to order that any child over 14 charged with an indictable offence may be proceeded against in an ordinary court.

3157 (15th ed.).

32 Id. at 665 .
} 
formed consent, i.e., it must be freely given after a reasonable and understandable explanation of the treatment. ${ }^{33}$ An exception to the general rule requiring consent before a medical or surgical treatment is undertaken is found in the emergency situation. Lord Nathan suggested that:: ${ }^{14}$

To justify operating without consent there must be a necessity for immediate action if the life or health of the patient is to be preserved.

In the event a physician is found liable in battery for an unauthorized medical treatment, damages will include compensation for any injuries suffered as a result of the battery, or even if no physical damage is suffered-since damages for an intentional tort such as battery are per se, substantial rather than nominal damages will be assessable. ${ }^{35}$ It would also seem that if a patient succeeds in an action for battery he may stand a better chance of receiving punitive damages than if his action was framed in negligence. ${ }^{36}$

(b) Position with respect to the prescription of contraceptives to minors

The problem to be examined in this section of the paper is what contraceptive treatments may subject a physician to liability for battery if it was to be held that a particular minor was incapable of giving a valid consent. The two main treatments of concern here are the prescription of birth control pills and the insertion of intrauterine devices. With respect to the fitting of intrauterine devices, it would seem fairly certain that this involves a surgical procedure and as such would amount to a battery if no valid consent was obtained.

What of the position with respect to the prescription of the pill? There is definitely no surgical procedure involved, but is there an "application of force" within the technical definition of "battery"? Salmond states: 37

Intentionally to bring any material object into contact with another's person is a sufficient application of force to constitute a battery.

Lord Nathan suggests that the mere administration of a drug may technically constitute a battery: ${ }^{38}$ "It is a technical assault, therefore, secretly to administer a drug to a patient against his wishes." Of course, in the normal situation, the minor receiving a birth control pill would certainly be aware of what they were and would indeed wish to receive them. If, however, it was held that she was incapable of giving consent would the situation be the same?

A recent article in the United States makes a similar suggestion: ${ }^{39}$

Since a battery requires only that the actor intentionally and without consent set in motion a force which ultimately produces a contact, it is possible that any unauthorized medical treatment will also be held to constitute a battery. The physician might therefore commit a battery merely by prescribing a drug for a minor without the consent of the minor's parent.

is See e.g. Halushka v. University of Saskatchewan (1965) 53 D.L.R. (2d) 436 (Sask. C.A.); and Mulloy v. Hop Sang [1935] 1 W.W.R. 714 (Alta. A.D.).

i" Nathan, supra, n. 4 at 165.

3s See Mulloy v. Hop Sang, supra, n. 33 at 716.

th See, McCoid, A Reappraisal of Liability for Unauthorized Medical Treatment. (1957) 41 Minn. L.R. 382; this article is also very valuable for its exhaustive comparison of negligent malpractice and battery.

37 Supre, n. 31 at 157.

Nathan, supra, n. 4 at 157.

14 Kavanaugh, Minors and Contraceptives: The Physician's Right to Assist Unmarried Minors in California. [1972] 23 Hastings L.J. 1486 at $1498-1499$. 
In order to better determine the validity of these suggestions one should perhaps examine in more detail the cases cited as authority for these propositions. Lord Nathan cites a note found in the medico-legal column of the British Medical Journal ${ }^{40}$ concerning an unreported case where a physician was found liable for secretly administering a sedative to an over-wrought patient who had refused such medication. The learned judge had found that the physician was liable in contract. However, the author goes on to suggest: ${ }^{41}$

Presumably to administer a drug without a person's knowledge is a common assault, but if no ill effects were caused the damages could not be more than nominal unless the court desired to make them exemplary. The assault might also constitute a trivial criminal offence. It would not come under the special provisions of the Offences against the Person Act against the administration of a noxious thing.

Since the case was decided in contract, it can hardly be said to be good authority for the above statement. In fact no case has been found in Canadian or English jurisprudence which suggests a doctor would be liable in battery for the unconsented administration or prescription of a pill or drug. Presumably no such action would be undertaken if a particular drug is satisfactory. If on the other hand it were to cause ill effects, the action would probably be based on negligence. ${ }^{42}$

Kavanaugh cites two cases as authority for his position. Firstly, in Commonwealth v. Stratton, ${ }^{43}$ the defendant was held guilty of criminal assault and battery for secretly administering some "love powder" (cantharides or more commonly called "spanish fly") in a quantity of figs and presenting them to a young lady whereupon she became violently ill. In the second case, State v. Monroe,44 a druggist was found guilty of criminal assault and battery for adding some croton oil (a rather drastic cathartic and pustulant) to a piece of candy in concert with others as a practical joke. Kavanaugh submitted that the definitions of criminal and tortious battery are similar enough that these criminal cases could equally apply to the tortious situation. ${ }^{45}$

Whatever the position may be in the United States, it was and is far from clear in English law. In the early English case of $R$. v. Bulton ${ }^{46}$ the defendant was found guilty of common assault for administering cantharides to some coffee. This case was expressly disapproved in $R$. v. Bilworth and Smith ${ }^{47}$ and again in $R$. v. Walhen ${ }^{48}$ and $R$. v. Hanson. ${ }^{49}$ The confusion for our purposes, is shown in the report of the Hanson case. It was argued for the prisoner that: ${ }^{50}$

... [T] law nor an assault. It was nothing more than a private wrong, the remedy for which was by a civil action, and not by a criminal proceeding (emphasis added).

Unfortunately we will never know what the result of a civil action

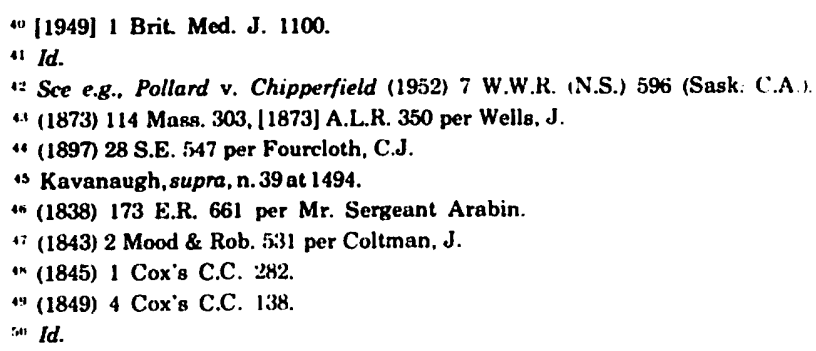


would have been since none apparently was brought. The judgment of Williams, J. also gives no clue:51

Williams, J. (after consultation with Cresswell, J.), said that he was of opinion that the indictment could not be sustained, as the offence charged was not either an assault or a common law misdemeanour. His lordship added that they were also of opinion that the case was not within 7 Will. 4 \& 1 Vict. c. 84 , which made it a felony to deliver to anyone any dangerous or noxious thing with intent to do grievous bodily harm.

The criminal law position was cleared up in 1860 with the passage of 23 Vict. c. 8, which made it a crime to administer a poison even where the intent was not to commit murder but only to inflict bodily harm. The modern versions of this old English statute are found in sections 229 and 230 of the Criminal Code. Unfortunately these do nothing to clear up the position in tort law.

In summary then, it would appear that the question of whether the simple giving of a pill can amount to the tort of battery is far from settled. It is clear under the Criminal Code that if the pill were a noxious or stupefying drug given with the requisite mala fides a criminal offense is committed. Whether or not the giving of a pill could amount to such an "application of force" as to constitute the tort of battery is at best doubtful-at least until there is some case authority on the point.

\section{Possible Criminal or Quasi-Criminal Liabilities}

\section{(a) The Criminal Code and the Food and Drug Act}

Under the former Criminal Code, 52 it was an offence to sell or advertise contraceptives. The relevant section was 150(2)(c) and was found in Part IV of the Criminal Code-Offences Tending to Corrupt Morals. It read as follows:

150. (2) Every one commits an offense who knowingly, without lawful justification or excuse ...

(c) offers to sell, advertises, publishes an advertisement of, or has for sale or disposal any means, instructions, medicine, drug or article intended or represented as a method of preventing conception or causing abortion or miscarriage ... (emphasis added).

Though this section was seldom used it remained on the books until 1969 when Parliament passed an Act to amend the Food and Drugs Act, the Narcotic Control Act and section 150(2)(c) of the Criminal Code. By section 13 of S.C. $1968-69$, c. 41 , the words in italics above ("preventing conception or") were dropped from section 150(2)(c) so that it is no longer a criminal offence to advertise or sell contraceptives. Before examining the Food and Drug Act amendment it is important to note the apparent change in public policy implicit in this amendment. It would seem to make it more clear that it is not absolutely against public policy to prevent conception. This is important for if it were against public policy, any consent to a treatment to prevent conception would be invalid.

While both the advertising and sale of contraceptives were taken out of the scope of the Criminal Code by this amendment, at the same time the regulation of their advertising was included in the Food and Drug

S1 Id. at 179.

s2 S.C. $1953-54$, c. 51 . 
Act. Section 2 of S.C. 1968-69, c. 41, added subsection (3) to section 3 of the Food and Drug Act:53

3. (3) Except as authorized by regulation, no person shall advertise to the general public any contraceptive device or any drug manufactured, sold or represented for use in the prevention of conception.

Pursuant to this section regulations have been passed on two separate occasions:

1. Occasion $\# 1^{54}$

C.01.625. Contraceptive drugs that are manufactured, sold or represented for use in the prevention of conception and that are not listed in Schedule F may be advertised for other than commercial purposes to the general public by

(a) any person who has no commercial interest in the manufacture, sale or distribution of such drugs, or

(b) any department or agency of the Government of Canada or a province or any municipality in Canada,

in connection with the bona fide dissemination of information on birth control or family planning.

K.01.001. Contraceptive devices, other than intra-uterine contraceptive devices, that are manufactured, sold or represented for use in the prevention of conception may be advertised for other than commercial purposes to the general public by

(a) any person who has no commercial interest in the manufacture, sale or distribution of such devices, or

(b) any department or agency of the Government of Canada or a province or any municipality in Canada,

in connection with the bona fide dissemination of information on birth control or family planning if the means of advertising is other than the dis. tribution of such devices door to door or through the mail as samples.

[Schedule F contains only the drug "thalidomide".]

2. Occasion $\# 2^{55}$

\section{SCHEDULE NO. 123}

1. Section C.01.625 of the Food and Drug Regulations is revoked and the following substituted therefore:

C.01.625. Contraceptive drugs that are manufactured, sold or represented for use in the prevention of conception and that are not listed in Schedule F may be advertised to the general public.

2. Section K.01.001 of the said Regulations is revoked and the following substituted therefore:

K.01.001. Contraceptive devices, other than intra-uterine contraceptive devices, that are manufactured, sold or represented for use in the prevention of conception may be advertised to the general public where the means of advertising is other than the distribution of samples of such devices door to door or through the mail.

The present position then, would appear to be that all forms of contraceptives may be sold without any criminal sanction and all forms of contraceptives may be advertised to the general public except intrauterine devices. The relevance of these provisions under the Food and Drug Act are that they indicate it is not against public policy in Canada to advertise, sell or, presumably, counsel the use of, or use contraceptive pills or devices. It could not therefore be argued that public policy with respect to birth control itself is a reason to vitiate the con-

\footnotetext{
sil See R.S.C. 1970, c. F.27.

it S.O.R./69-417, (1969) 103 Canada Gazette (Part II) 1170. August 27, 1969.

is S.O.R./70-29. (1970) 104 Canada Gazette (Part II) 80, January 14, 1970.
} 
sent of minors to contraceptive treatment. In short, there is no statute in Canada which specifically imposes criminal or quasi-criminal penalties on a physician for prescribing contraceptives to anyone in general or to minors specifically. As a matter of fact, even before the Criminal Code amendment, there was no law in Canada preventing a physician from prescribing contraceptives to his patients or a patient's use thereof. 56

\section{(b) The Juvenile Delinquents Act}

An oft-mentioned possible legal pitfall for doctors who prescribe contraceptives to minors, has been the possibility of being found guilty of contributing to juvenile delinquency.57 In the periodical articles noted on this subject, though the possibility of such a conviction was mentioned, all concluded that there was very little probability. In fact no recorded case has been found in North America or England in which a physician has been convicted or for that matter, charged, with such an offence.

As any lawyer would be quick to point out, however, simply because no such charges have been laid against physicians, that is not to say they never could be. Therefore, it may be useful to examine some important sections of the Juvenile Delinquents Act, R.S.C. 1970, c. J-3, and cases pertinent thereto. The relevant sections are:

2. (1) In this Act...

"juvenile delinquent" means any child who violates any provision of the Criminal Code or of any federal or provincial statute, or of any by-law or ordinance of any municipality, or who is guilty of sexual immorality or any similar form of vice, or who is liable by reason of any other act to be committed to an industrial school or juvenile reformatory under any federal or provincial statute;

33. (1) Any person, whether the parent or guardian of the child or not, who knowingly or wilfully,

(a) aids, causes, abets or connives at the commission by a child of a delin. quency, or

(b) does any act producing, promoting, or contributing to a child's being or becoming a juvenile delinquent or likely to make any child a juvenile delinquent

is liable on summary conviction before a juvenile court or a magistrate to a fine not exceeding five hundred dollars or to imprisonment for a period not exceeding two years, or to both....

(4) It is not a valid defence to a prosecution under this section either that the child is of too tender years to understand or appreciate the nature or effect of the conduct of the accused, or that notwithstanding the conduct of the accused the child did not in fact become a juvenile delinquent....

The main problem with these sections is the very wide definition of "juvenile delinquent" which includes any "child" who is "guilty of sexual immorality". The term "sexual immorality" is undefined in the Act nor has it been satisfactorily explained in the case law. The problem was aptly expressed in the report of the Department of Justice Committee on Juvenile Delinquency: ${ }^{58}$

364. There is still another source of potential prejudice to an accused charged with contributing to delinquency. This arises from the inherent difficulty of the con-

36 See Green, Family Planning and Canadian Law, (1964) Applied Therapeutics 331.

s) See e.8., Pilpel \& Wechsler, supra, n. 26 at 30; Pilpel \& Wechsler, Birth Control, Teen-Agers and the Law: A New Look, 1971. (1971) 33 Fam. Planning Perspectives 37; Kavanaugh, supra, n. 39 at 1496; Holder, Minors and Contraception, (1971) 216 J.A.M.A. 2059.

s* Macleod, et al., Juvenile Delinquency in Canada, 209 (1965). 
cept of contributing to delinquency as an offence category. For what, in fact, does contributing to delinquency mean? And what limits should be observed in receiving evidence in support of a change? ... While it is beyond the scope of this Report to trace the development of Canadian case law on the contributing provisions, we should say frankly that in our judgment the courts have yet to articulate a clear test for distinguishing between permissible and prohibited conduct. In many cases, therefore, liability to a criminal sanction will depend almost entirely upon the subjective, and sometimes highly speculative, assessment of the judge as to whether particular conduct is or is not such as to contribute to the delinquency of a child. It is true that the statute provides that it is not a defence to a charge of contributing "that the child is of too tender years to understand or appreciate the nature or effect of the conduct of the accused, or that ... the child did not in fact become a juvenile delinquent." In interpreting this provision the courts have said that it was "the evident intention of Parliament ... to relieve the Court of the necessity of speculating as to whether or not the child's morals were in fact undermined. . ." $[R$. v. Hamlen (1939) 1 W.W.R. 702]. Nevertheless, the judge is often forced by reason of the indefinite character of the concept of contributing to delinquency to make precisely this kind of assessment [R. v. Cortner (1961) 35 W.W.R. 187; $R$. v. MacDonald (1936) 3 D.L.R. 446].

The end result is that it is not at all clear under the Act or cases, whether a sexually active "child" (in Alberta under 18 for girls, 16 for boys) would be considered to be a "juvenile delinquent" by reason of sexual immorality. Perhaps it would be easier for a judge to find a sexually active minor "guilty of sexual immorality" the younger the minor in question was. There is no authority for this proposition, however, nor any suggestion at how young an age sexual activity becomes "sexual immorality" or even whether age has anything to do with it. In any case there is great difficulty encountered in trying to glean some sort of general principle, applicable to all the cases, out of the extremely loose wording of the Juvenile Delinquents Act.

Perhaps from the practical legal point of view it would be preferable to concentrate on a physician's possible liability under section 33 if the particular minor he was treating was adjudged to be both sexually immoral and a juvenile delinquent.

It is suggested that in the event a doctor were charged under section 33 , it would be very difficult for the Crown to prove the necessary mens rea requisite to the commission of the offence. In the normal case a physician would not be interested in prescribing contraceptives to a minor in order to encourage sexual promiscuity, but rather in the interests of the minor's good health. As one article recently put it: 59

On the possiblity that such a prosecution might be instituted, we think the physician would be well advised to defend on the ground that the minor had been sexually active, and that in his best professional judgment, he felt that failure to prescribe contraceptives would subject the minor, or the out-of-wedlock children whom she would be likely to bear, to serious health hazards. An argument could certainly be made that the physician's actions (like most medical treatment) were independent of the "delinquent" conduct of the patient, and were intended and needed to avoid adverse health effects of such conduct.

It should be noted that a physician could not defend a charge of contributing to juvenile delinquency by pleading that the child was already delinquent. ${ }^{60}$ If an accused contributes to a child's continuing to be a delinquent, or to likely becoming a juvenile delinquent, that con-

\footnotetext{
: Pilpel and Wechsler, supra, n. 26 at 30.

a See R. v. Van Balkem |19.44| I W.W.K. 347 (B.C. Mag. Ct.); R. v. ('hristahus [1!4ti] I W W.K. liti IMan C.A.I.
} 
duct is enough for a conviction. ${ }^{61}$ However, in order for the Crown to prove the offence it would seem that the cases establish that it must be shown there was such conduct as would in fact-and not merely in theory-endanger a child's morals or contribute to his continuing bad morals. ${ }^{62}$ Aside from the difficulty of trying to show a physician was "knowingly or wilfully" contributing to delinquency by prescribing contraceptives, it is submitted that it would be difficult to show a causal connection between the prescription of contraceptives and the sexual immorality of the patient.63

In any event a recent case in Quebec, $X$ v. La Reine ${ }^{64}$ may indicate a changing judicial outlook with respect to what sort of conduct constitutes "sexual immorality". In that case the accused, aged 19, won an appeal from a conviction of contributing to juvenile delinquency by having sexual relations with his 16 year old girl friend. Important for our purposes is the fact that the court found that extra-marital sexual relations with a minor are not necessarily criminal nor immoral. The headnote of the case is as follows:

1. Des relations sexuelles, trois ou quatre fois en six mois, d'un adulte de 19 ans avec une fille de 16 ans, qui y consent, ne constituent pas nécessairement et absolument, dans l'opinion du tribunal, un comportement immoral, incorrigible et antisocial.

2. Les relations sexuelles épisodiques, admises dans le présent cas, semblent constituer plutôt une manifestation imprudente mais normale et impulsive d'amour qu'une incitation à la délinquance.

3. Le délit "d'avoir posé un acte d'immoralité sexuelle", mal défini ou pas assez défini, peut conduire à des abus qui obligent le juge à la modération et circonspection dans l'appréciation de la preuve.

4. Les art. $2 \mathrm{~h}$ et 33 de la Loi sur les jeunes délinquants [1952 S.R.C. c. 160] peuvent, tout au plus, créer une présomption juris tantum.

The significance of the case is that it indicates that even if a causal connection could be shown between a physician's prescription of contraceptives to a minor, and the sexual activities of the minor, it could not be presumed the physician knew these activities were immoral per $s e$. One other case of significance in this area comes from the United States, The State v. McLaughlin. ${ }^{65}$ In that case the defendant was charged and convicted at trial of contributing to the delinquency of her 16 year old daughter who had by that age already given birth to three illegitimate children. The conduct which allegedly gave rise to this delinquency was the mother's warning to her daughter to use birth control devices if she persisted in her sexual activity and the instructions to her daughter as to their use. Such counselling, it was alleged, encouraged the child to engage in immoral sexual activities causing her to become a delinquent. Obviously Mrs. McLaughlin was either sadly

B! See R. v. Miller [1944] 1 W.W.R. 415 (Sask. Dist. Ct.); See also R. v. Hamlin [1939] 1 W.W.R. 703 (B.C.S.C.).

62 See e.g., R. v. Bloomstrand (1952) 6 W.W.R. (N.S.) 680 (Sask. C.A.); R. v. Vahey [1932] 3 D.L.R. 95 (Ont. S.C.) aff'd [1932] 4 D.L.R. 656 (Ont. C.A.); cf. R. v. Stundon (1962) 40 W.W.R. 565 (Sask. C.A.). For an extensive treatment of mens rea in the offence of contributing to juvenile delinquency, see Parker, Mens Rea and Contributing to Juvenile Delinquency, (1963) 28 Sask. Bar Rev. 79.

5.) See e.8., recent medical studies in the United States which suggest that the sexual habits of sexually active minors change very little whether or not prescription contraceptives are available. Gordis et. al., Adolescent Pregnancy: A Hospital-Based Test Program for Primary Prevention, (1968) 58 American Journal of Public Health 849 at 857; Goldsmith et al., Teenagers, Sex and Contraception, (1972) 4 Fam. Planning Perspectives 32; Katner \& Zelnik, Sexual Contraception and Pregnancy Experience of Young, Unmarried Woman in the U.S., (1973) a reprint of two articles in October 1972 and January 1973 issues of Fam. Planning Perspectives.

64 [1969] R.L. 122 (Cour Superieure En Appel).

6.) (1965) 212 N.E. (2d) 635 (Ohio C.A.). 
lacking as an instructor on birth control or we can assume her counselling had little effect on her daughter's overzealous sexual activity. In any event the conviction gained at trial was overthrown by the Ohio Supreme Court, largely on the ground that the conviction violated the mother's freedom of speech: 66

A mother's instructions to her pregnant daughter that birth preventive measures should be used in premarital sexual acts did not create a "clear and present danger" of an evil which the state could prevent by abridgement of constitutionally guaranteed right of free speech; neither was there a "clear and present danger" of accomplishing the prohibited crime, i.e., contributing to the delinquency of a minor.

Though these technical legal reasons may not be applicable in Alberta it is relevant to note that if a mother cannot be legally "blamed" in this manner for her daughter's promiscuity, it is very doubtful a physician who prescribed drugs for such a girl could be held liable. Shortly, concluding this section of the paper, then, it would generally appear very unlikely that a medical doctor would be held liable for contributing to a child becoming a juvenile delinquent by reason only of his prescribing contraceptives to that child. This statement can be made with the most certainty with respect to older minors. Perhaps the younger the child, the more possibility there is of conviction. In the writer's opinion the prescription of contraceptives to minors under the age of 14 could be risky with respect to possible liability under the Juvenile Delinquents Act, since Parliament has provided in the Criminal Code that unmarried minor females under that age can never consent to sexual intercourse. In principle the permission of parents with respect to the prescribing of contraceptives to girls under 14 should make no difference to possible criminal liability. In practice, however, if such permission were obtained, it would seem unlikely a charge would arise.

\section{(c) Professional disciplinary proceedings}

Even though a physician may feel relatively safe from civil or criminal liability by reason of his giving contraceptive treatment to a particular minor, he may still face the very real possibility of disciplinary proceedings the consequences of which may be even more serious than the former two liabilities. This possibility was discussed infra when the $R e$ " $D$ " case was considered.

As was mentioned earlier this case really gives little guidance as to the legal issue involved. It would seem to leave a great deal of discretion in the hands of a particular medical inquiry committee. Unless a provincial medical association had outlined definite guidelines for its members, it would seem the rule would be a particular committee's interpretation of what age, if any, a physician could treat a minor without parental consent without committing unprofessional conduct.

At the present time in Alberta, until the Alberta Medical Association lays down some specific quidelines with respect to unprofessional conduct and the treatment of minors, a physician could well find himself facing disciplinary proceedings on the complaint, for example, of irate parents of a minor female under the age of 16 (or perhaps even 16-17) who was given contraceptive treatment without parental consultation. It should be mentioned here that the possibility of disciplinary action

in Id. (from the headnote). 
being instituted for such treatment of 16 or 17 year olds may now be lessened since the Scientific Council of the Canadian Medical Association recently passed a resolution (July, 1973) recommending that the Federal Government encourage the provinces to adopt legislation making the age of consent to medical treatment $16 .{ }^{67}$ It should also be mentioned, of course, that whatever may be the ethical position of particular medical associations, it has nothing to do with the legal position with respect to possible civil or criminal liability and is only relevant to possible liability to disciplinary actions within the profession itself.

\section{CONCLUSIONS AND RECOMMENDATIONS}

On the basis of the foregoing it is submitted the following conclusions can be reached:

1. It would appear that there has developed in the common law a rule whereby a mature minor can validly consent to medical treatment and a medical practitioner can rely upon this consent without the necessity of obtaining parental concurrence.

2. The age at which a minor can be considered mature enough to consent to medical treatment would depend largely upon two factorsthe individual maturity of the minor and complexity or seriousness of the treatment. This is true since the two main factors of an "informed consent" are knowledge of and understanding of the nature of the risks involved.

3. Turning to the specific problem of the prescription of contraceptives to minors it would appear:

(i) Doctors would face the most possibility of both civil and criminal liability in prescribing contraceptives for unmarried minors under the age of 14. Parental consent would be a valid defence to civil liability in such cases, but would not appear to have any effect on the possibility of criminal liability (other than the practical effect that there would be less chance of a complaint arising when parental consent was obtained).

(ii) In prescribing contraceptives to unmarried minors of 14-15 years of age, a doctor probably faces little possibility of civil or criminal liability (under the Juvenile Delinquents Act). He may, however, face disciplinary proceedings within the medical profession if he goes ahead without consulting the minor's parents.

(iii) A physician is probably in the safest legal position in prescribing contraceptives to minors in the 16 and 17 year old age group. Minors in this age group would generally be the most capable (allowing for individual variances) of making a reasoned decision concerning contraceptive treatment. In addition, minors in this age group who are seeking contraceptive advice and treatment, will most often already be sexually active thus making it easier for a doctor to justify the prescription of contraceptives as part of a total health treatment for the child.

It is, of course, realized that with the lack of case authority and statutory enactment many of the foregoing conclusions can only be

67. This resolution was noted in Report of the Ontario Commissioners on The Age Of Consent To Medical. Surgical and Dental Treatment, at 15-16 (1973). Whatever may be the C.M.A.'s position, it does not necessarily have the sympathy of Provincial Legislatures. Saskatchewan's Legislative Assembly recently voted down such proposed legislation-Noted in (1973) 107 Can. Med. Assoc. J. 76. 
speculative until the situation is clarified. Considering how few cases have arisen in the past on this subject, it is unlikely that the common law by itself will ever be totally clear in this area. With that in mind it may be useful to make the following recommendations.

(1) it is recommended that a specific and clear statute dealing with the consent of minors to medical treatment be enacted.

(2) it is recommended that this statute set out the age of 16 as the general age of consent for medical treatment. ${ }^{68}$

(3) it is recommended that this statute include a specific section saving the former exception to the requirement of consent of a minor's parents in the emergency situation.

(4) it is recommended that this statute also contain a specific section saving the "mature minor" rule for children under 16 in the some defined circumstances, i.e., a physician should be exempt from liability for battery where he has relied solely on the consent of a minor to fairly simple medical treatment which was fully understandable to the minor.

(5) it is also recommended that this statute specifically deal with the situation where a minor 16 or over (or a minor under 16 but fairly mature) and his parents or guardian dis. agree on whether or not to consent to a particular medical treatment.

(6) due to the possible conflict as to whether or not contraceptive treatment can be considered therapeutic medical treatment, it is recommended that this statute specifically deal with the question at what age a minor can consent to contraceptive treatment.

The age in recommendation \#6 should be the same as the age of consent to all other types of medical treatment. It is realized, however, that this is a very controversial problem and there are numerous differing opinions. Though it may not be very politically realistic to expect a legislature to deal squarely with the issue of contraception, it is felt that this is the only way in which that issue can be properly separated from the rest of the recommendations. If no specific section dealing with contraceptives were included in a draft of the proposed statute, the controversy over the age at which a minor could validly consent to contraceptive treatment might vitiate the beneficial effects of a statute much broader in scope.

6* For medical reasons it may be advisable to make specific exceptions to this rule, such as the minimum age of consent to blood donation being 18. See. Latey Report, para. 485-489. 